\title{
Cleanliness efficacy and effect on dentin microhardness of a novel plant extract irrigant
}

\author{
Maram E. Khallaf, Engy M. Kataia, Yousra Aly*, Nada Omar and M. Abdullah Mohamed
}

\begin{abstract}
Objective: This study was done to evaluate the effect of the prepared Moringa oleifera-based root canal irrigant compared to conventionally used irrigants on the microhardness of root dentin and smear layer removal.

Materials and methods: One hundred freshly extracted teeth with single root were divided into 5 groups according to the irrigant used: group 1, saline; group 2, Moringa oleifera; group 3, Moringa oleifera + chlorhexidine; group 4, chlorhexidine; and group 5, sodium hypochlorite. Root canal preparation was done using Protaper universal system till size F5 using one of the irrigants after each file. Fifty teeth were prepared to measure dentin microhardness, while the remaining fifty were prepared for evaluation of the remaining debris and smear layer using stereomicroscope and scanning electron microscope (SEM) in each third of the canal.

Results: Chlorhexidine alone and combined with Moringa oleifera showed higher microhardness values in apical and coronal parts. In the middle parts, chlorhexidine followed by Moringa oleifera showed the highest results. SEM examination showed that none of the used irrigants has the ability to completely remove smear layer. However, Moringa oleifera group showed the least amount of smear layer on canal wall.
\end{abstract}

Conclusions: Moringa oleifera is a promising final irrigant solution alone or combined with chlorhexidine throughout the instrumentation. Moringa oleifera was proved to have a high effect as a chelating agent.

Keywords: Irrigant, Microhardness, Moringa oleifera, Smear layer removal

\section{Background}

Proper cleaning and shaping of the canal prior to its obturation is the key of success of endodontic treatment (Muhammad et al. 2015). To achieve this purpose, different types of root canal irrigants and intracanal medicaments are used (Hasselgren et al. 1988). Sodium hypochlorite $(\mathrm{NaOCl})$ is the most commonly used irrigant for this purpose. It has many advantages such as tissue dissolving, antibacterial, and lubricant action (Zehnder et al. 2002; Siqueira Jr et al. 1998). However, it causes severe reaction when it gets in contact with periapical tissues (Pashley et al. 1985; Zhu et al. 2013). That is why researches are nowadays directed towards the use of non-toxic and more biocompatible herbal materials to be used as root canal irrigants. Examples of these new biocompatible materials are green tea, Emblica officinalis, Psidium guajava, neem, and Moringa oleifera (Ghonmode et al. 2013; Dubey 2016). Moringa oleifera (M. oleifera) is a plant that grows in many countries from South Asia to West and East Africa (Anwar et al. 2007). Moringa oleifera is a native Indian tree that showed an antiviral, antibacterial, antioxidant, antisclerotic, and anti-inflammatory properties. It has been used for treatment of malaria, malnutrition, colon cancer, and myeloma (Jung 2014).

\footnotetext{
* Correspondence: yousraaly2010@gmail.com

Restorative and Dental Materials Department, National Research Centre, Cairo, Egypt
}

\section{Springer Open}

(c) The Author(s). 2020 Open Access This article is licensed under a Creative Commons Attribution 4.0 International License, which permits use, sharing, adaptation, distribution and reproduction in any medium or format, as long as you give appropriate credit to the original author(s) and the source, provide a link to the Creative Commons licence, and indicate if changes were made. The images or other third party material in this article are included in the article's Creative Commons licence, unless indicated otherwise in a credit line to the material. If material is not included in the article's Creative Commons licence and your intended use is not permitted by statutory regulation or exceeds the permitted use, you will need to obtain permission directly from the copyright holder. To view a copy of this licence, visit http://creativecommons.org/licenses/by/4.0/. 


\section{Materials and methods}

\section{Specimen selection}

One hundred extracted single-rooted teeth were used in this study (National Research Centre project; Ethics Committee approval number 16/344).

Each tooth was radiographed to confirm the presence of a single canal. Teeth with previous root caries, cracks, curved canals, endodontic treatment, internal resorption, or calcification were excluded. After removal of calculus and soft-tissue debris, the teeth were placed in $2.5 \%$ sodium hypochlorite for $1 \mathrm{~h}$ to allow for surface disinfection and then stored in saline solution until instrumentation.

\section{Specimen preparation}

The teeth length was standardized to a length of $16 \mathrm{~mm}$. Teeth decoration was done using a safe-sided diamond disk mounted in a low-speed handpiece under a water coolant. The working length was measured by subtracting $1 \mathrm{~mm}$ from the length recorded when the tip of a \# $15 \mathrm{~K}$ file (Dentsply Maillefer, Switzerland) was visible at the apical foramen. Root canal preparation was done using Protaper (Dentsply, Maillefer) universal nickel titanium rotary system driven by $\mathrm{x}$-smart endomotor (Dentsply, Maillefer) till size F5 file.

\section{Grouping}

Teeth were divided into 5 groups $(n=20)$ according to the irrigant used, as follows: group 1, saline; group 2, $M$. oleifera (extracts were obtained from the Egyptian Scientific Society of the moringa trees, National Research Centre, Dokki, Giza, Egypt); group 3, M. oleifera in addition to chlorhexidine ( $\mathrm{CHX})$; group 4 , chlorhexidine; and group 5, sodium hypochlorite.

Irrigation was done by 3 milliliters $(\mathrm{ml})$ of irrigant solution according to each group after each file size. A final rinse was performed with $3 \mathrm{ml}$ distilled water.

\section{Microhardness testing}

Fifty teeth were used for this part. Teeth were sectioned into two halves using a carborundum disk to create a longitudinal groove on the buccal and lingual surfaces. The teeth were then split using a chisel and mallet. Teeth from each group were rinsed thoroughly with saline and mounted on acrylic cylinders with self-cure acrylic resin with the root canal facing up. The specimens' surfaces were finished using a silicon carbide paper in the following order: 400, 800, and 1200 grit. The microhardness measurements were done using a Vickers Diamond Microhardness Tester (Nexus 4000/ 60, INNOVATEST, Netherlands, Europe) in Vickers hardness units (VHN). At each root third, the microhardness measurements were taken at three different points at a depth of $500 \mu \mathrm{m}$ from the lumen. Each measurement was carried out by using a $300 \mathrm{~g}$ load for $15 \mathrm{~s}$ dwell time.

\section{Canal cleanliness and smear layer removal}

Fifty teeth were used for this part of the study. Each tooth was divided into equal sections of coronal third, middle third, and apical third with a diamond disk. Each slice was marked as coronal, middle, and apical to identify its site. Images of each third of the canal were taken using a Canon digital camera with magnification $\times 25$ connected to a Zeiss stereomicroscope (Technival 2). The captured images were analyzed using ImageJ software (Image $1.47 \mathrm{~V}$, National Institute of Health, USA). The percentage of debris on the entire surface area was analyzed in relation to the whole area of each one third of the canal (Fig. 3).

The samples were then air-dried, sputter-coated with gold using a fine coat ion sputter JFC-1100 (fine coat ion sputter JFC-1100, JEOL Ltd., Tokyo, Japan), and then evaluated using scanning electron microscope (SEM) (Jeol JSM-6360 LV, JEOL Ltd.). Samples were examined with magnification $\times 50,000$ and $\times 100,000$.

\section{Statistical analysis}

The mean and standard deviation values were calculated for each group in each test. Data were explored for normality using Kolmogorov-Smirnov and Shapiro-Wilk tests; the data showed parametric (normal) distribution.

Repeated measures ANOVA was used to compare between more than two groups in related samples. Pairedwise sample $t$ test was used to compare between two groups in related samples. One-way ANOVA followed by Tukey post hoc test was used to compare between more than two groups in non-related samples.

The significance level was set at $P \leq 0.05$. Statistical analysis was performed with $\mathrm{IBM}^{\odot} \mathrm{SPSS}^{\oplus}$ Statistics Version 20 for Windows.

Table 1 The mean and standard deviation (SD) of hardness in each third in different groups

\begin{tabular}{|c|c|c|c|c|c|c|c|}
\hline \multirow[t]{3}{*}{ Variables } & \multicolumn{7}{|c|}{ Hardness } \\
\hline & \multicolumn{2}{|l|}{ Apical } & \multicolumn{2}{|l|}{ Middle } & \multicolumn{2}{|c|}{ Coronal } & \multirow[t]{2}{*}{$\boldsymbol{p}$ value } \\
\hline & Mean & SD & Mean & SD & Mean & SD & \\
\hline Group 1 & 60.57 & 3.16 & 63.73 & 2.85 & 73.10 & 12.74 & $0.292 \mathrm{~ns}$ \\
\hline Group 2 & 83.90 & 5.01 & 79.03 & 9.92 & 71.30 & 3.02 & $0.304 \mathrm{~ns}$ \\
\hline Group 3 & 95.60 & 7.61 & 65.33 & 5.10 & 87.33 & 7.15 & $0.025^{*}$ \\
\hline Group 4 & 99.17 & 2.36 & 89.23 & 6.22 & 82.87 & 12.97 & $0.295 \mathrm{~ns}$ \\
\hline Group 5 & 61.37 & 2.95 & 72.30 & 2.15 & 76.77 & 3.24 & $0.028^{*}$ \\
\hline$p$ value & \multicolumn{2}{|c|}{$<0.001^{*}$} & \multicolumn{2}{|l|}{$0.002^{*}$} & \multicolumn{2}{|c|}{$0.228 \mathrm{~ns}$} & \\
\hline
\end{tabular}

ns non-significant $(p>0.05)$

*Significant $(p<0.05)$ 


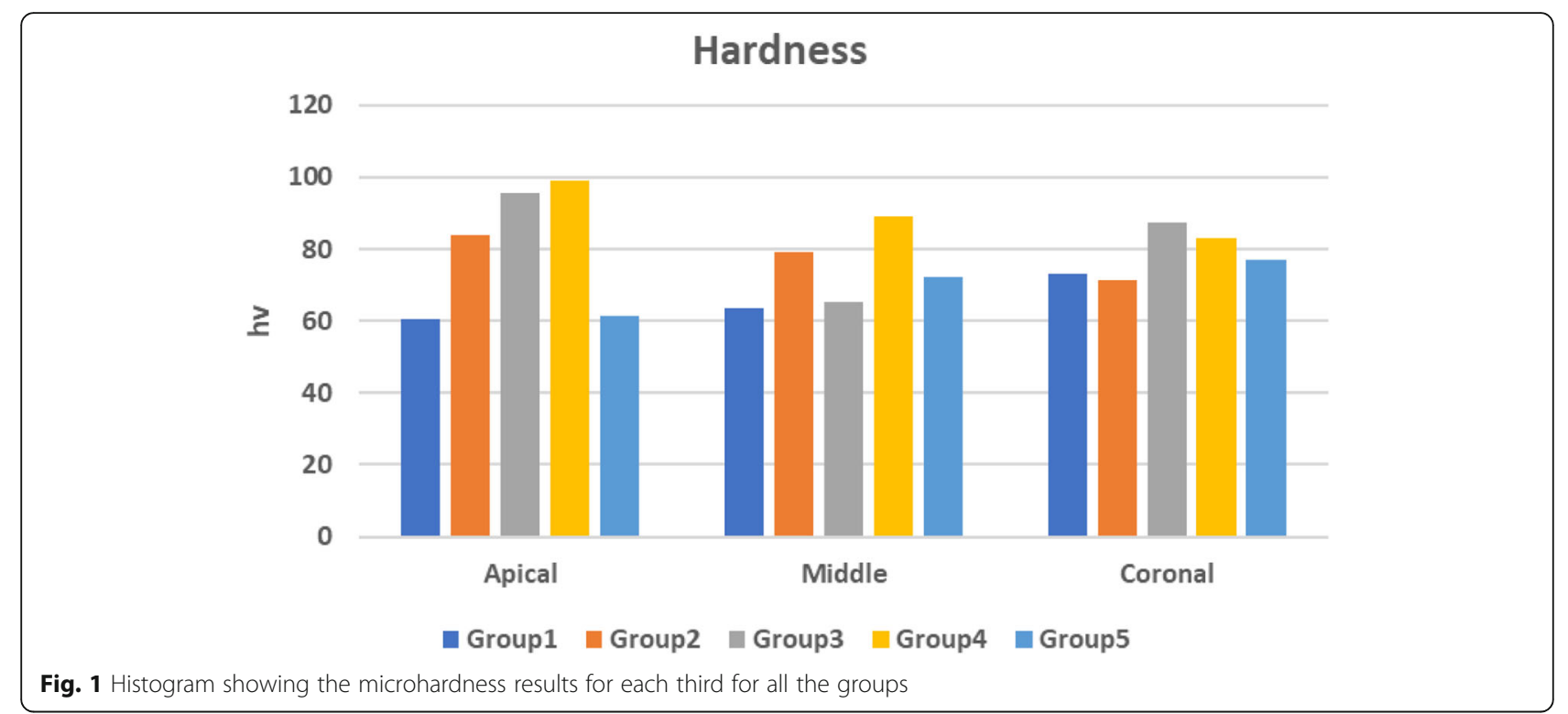

\section{Results}

Microhardness results (Table 1 and Figs. 1 and 2)

No statistically significant difference was found between apical, middle, and coronal thirds in group 1 (saline), group 2 (M. oleifera), and group 4 (CHX). In group 3 (M. oleifera and $\mathrm{CHX}$ ), a statistically significant difference was found between the three thirds, where the highest mean value was found in apical third followed by coronal, then middle. In group $5(\mathrm{NaOCl})$, a statistically significant difference was found between apical and coronal thirds where the highest mean value was found in the coronal third.

A statistically significant difference was found among the different groups in the apical and middle thirds.
While no significant difference was found in the coronal third.

Remaining debris evaluation results (Table 2 and Figs. 3, 4 , and 5)

In group 1, a statistically significant difference was found between the coronal and each of the middle and apical third where $p=0.027$ and $p=0.012$ respectively. In groups 2 and 3 , a statistically significant difference was found between the apical and coronal thirds where $p=$ 0.042 . In group 4 , a statistically significant difference was found between the apical and each of the middle and coronal thirds where $p=0.008$ and $p=0.013$ respectively. In group 5, no statistically significant difference

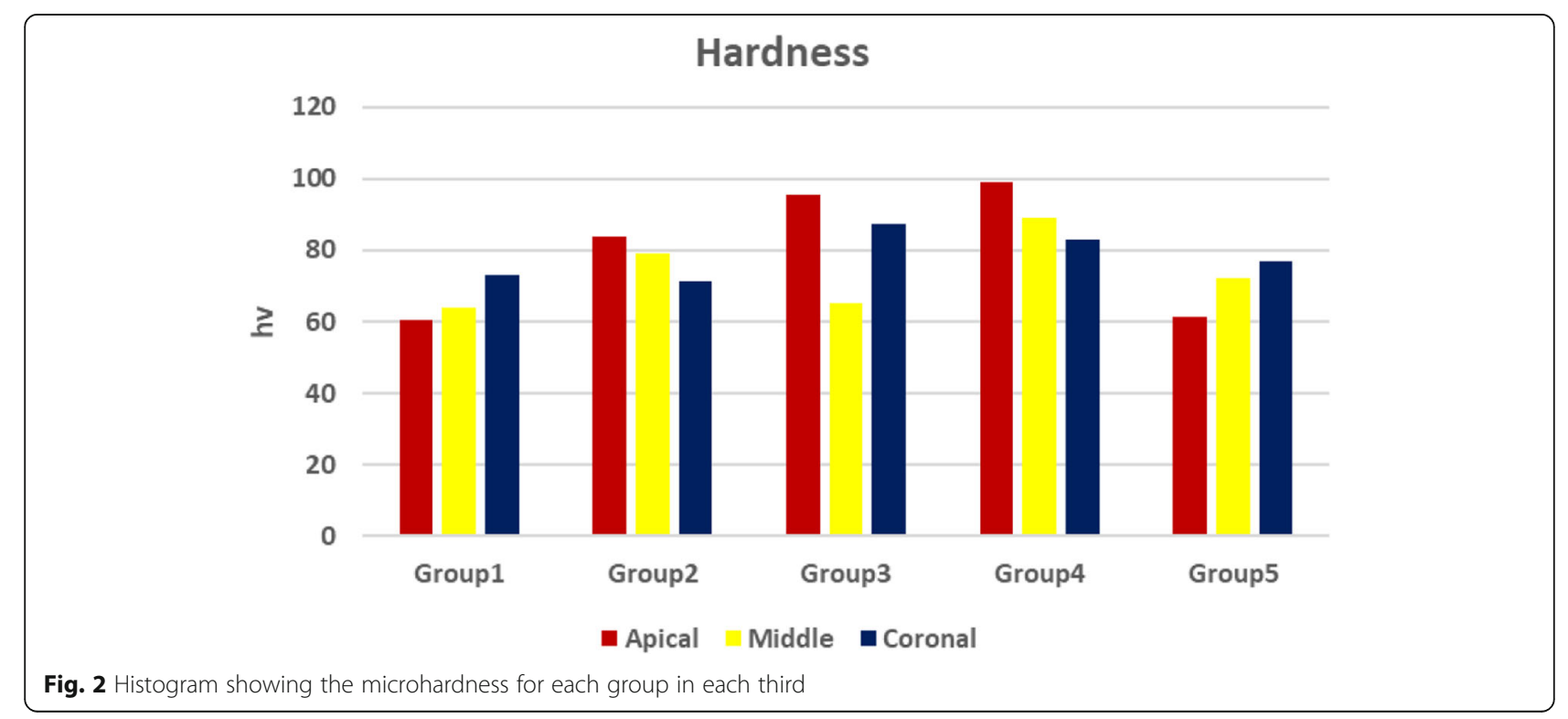


Table 2 The mean and standard deviation (SD) of debris percentage in each third in different groups

\begin{tabular}{|c|c|c|c|c|c|c|c|}
\hline \multirow[t]{3}{*}{ Variables } & \multicolumn{7}{|c|}{ Debris percentage } \\
\hline & \multicolumn{2}{|l|}{ Apical } & \multicolumn{2}{|l|}{ Middle } & \multicolumn{2}{|c|}{ Coronal } & \multirow[t]{2}{*}{$\boldsymbol{p}$ value } \\
\hline & Mean & $\mathrm{SD}$ & Mean & SD & Mean & $\mathrm{SD}$ & \\
\hline roup 1 & 32.85 & 20.95 & 24.33 & 13.68 & 14.80 & 11.67 & $0.020^{*}$ \\
\hline Group 2 & 10.30 & 6.80 & 5.83 & 5.72 & 1.30 & 2.01 & $0.041^{*}$ \\
\hline Group 3 & 35.75 & 23.32 & 11.79 & 15.92 & 5.29 & 8.19 & $0.032^{*}$ \\
\hline roup 4 & 29.23 & 11.24 & 9.17 & 5.39 & 6.05 & 2.15 & $0.005^{*}$ \\
\hline Group 5 & 35.08 & 22.32 & 25.70 & 22.55 & 13.77 & 5.17 & $0.115 \mathrm{~ns}$ \\
\hline$p$ value & \multicolumn{2}{|c|}{$0.192 \mathrm{~ns}$} & \multicolumn{2}{|c|}{$0.128 \mathrm{~ns}$} & \multicolumn{2}{|l|}{$0.024^{*}$} & \\
\hline
\end{tabular}

ns non-significant $(p>0.05)$

*Significant $(p<0.05)$

was found between the apical, middle, and coronal thirds where $p=0.115$.

\section{SEM evaluation}

SEM examination showed that none of the used irrigants has the ability to completely remove smear layer. However, the $M$. oleifera group showed the least amount of smear layer on the canal wall (Figs. 6, 7, 8, 9, and 10).

\section{Discussion}

A number of chemicals have been previously investigated as irrigants to remove smear layer. The sodium hypochlorite solution $(\mathrm{NaOCl})$ has been the mostly used irrigant for over four decades due to its proven effective antibacterial properties and its excellent action as an inorganic solvent material. However, high concentrations of $\mathrm{NaOCl}$ showed toxic effect to the periapical tissues (Ferraz et al. 2001; Kuruvilla and Kamath 1998).

That is why researches are now shifted towards the creation of more compatible irrigant solutions based on natural herbs. In many studies, chlorhexidine gluconate was proved to be an effective endodontic irrigant. Chlorhexidine could clear the microorganisms persisting in the root canal, even after biomechanical preparation, due to its adsorption capacity and slowly liberated active cations by the dental tissues, which lead to successful root canal therapy (Ayhan et al. 1999; Leonardo et al. 1999). Chemicals used for root canal irrigation may lead to changes in chemical and physical properties of root dentin (Cruz-Filho et al. 2011). Moreover, decrease in the dentin microhardness can affect the adhesion and sealing ability of the sealers to the root dentin walls

\section{A}

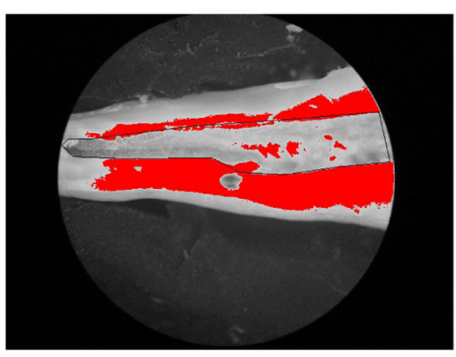

$\mathrm{C}$

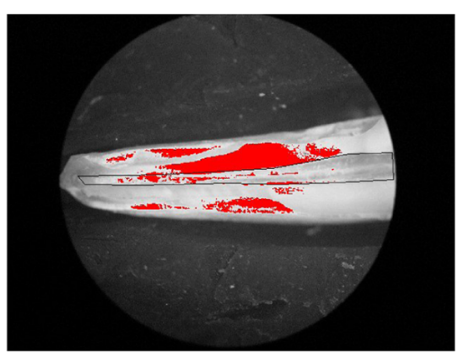

B

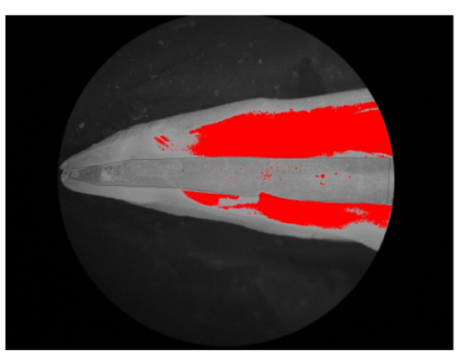

$\mathrm{D}$

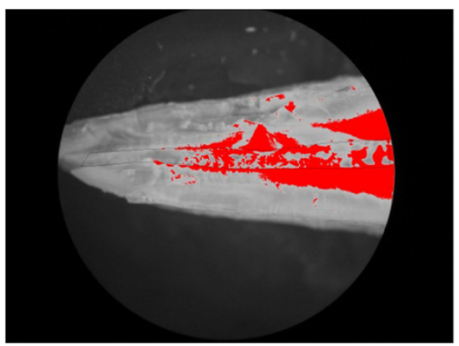

$\mathrm{E}$

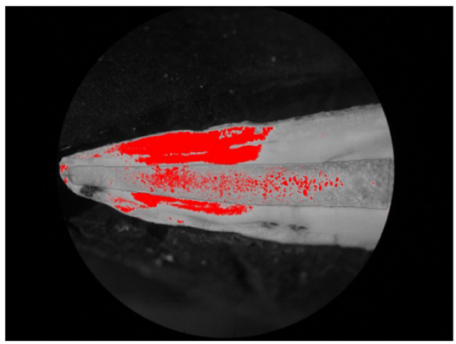

Fig. 3 Image analysis of stereomicroscope images ( $\times 25)$ showing remaining debris (red) in the apical third of the different groups: a group 1, b group 2, c group 3, d group 4, and e group 5 


\section{Debris percentage}

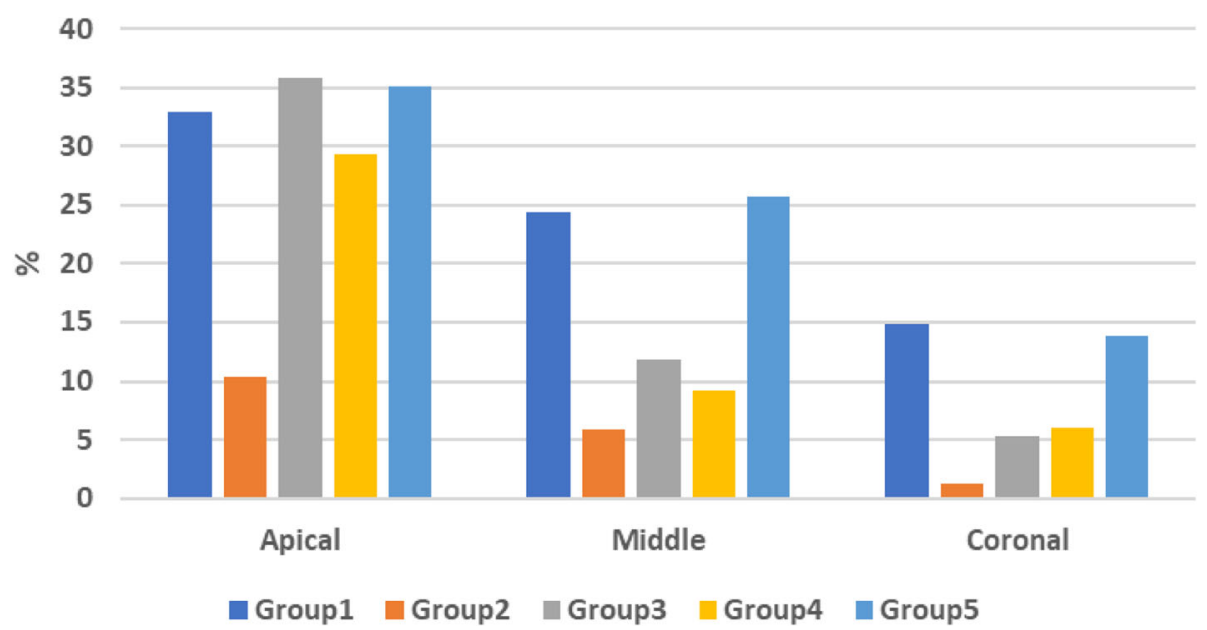

Fig. 4 A histogram showing the percentage of debris found in each third for each group

(Zehnder 2006). Irrigation with a tissue-dissolving antimicrobial solution is essential for effective removal of the smear layer and remnant pulp debris from the root canals. No irrigant can completely achieve total debridement of the root canal system; thus, the combination of more than one solution is necessary to achieve this goal (Zehnder 2006; Agrawal Vineet et al. 2014). In this study, a comparison of the effect on dentin microhardness and smear layer removal of the new irrigant solution $M$. oleifera (extracts were obtained from the Egyptian Scientific Society of the moringa trees, National Research Centre, Dokki, Giza, Egypt), M. oleifera +
$\mathrm{CHX}, \mathrm{CHX}$ solution, $\mathrm{NaOCl}$, and saline solution was done. The microhardness measurement was performed at the coronal, middle, and apical third of the root canal dentin. Mean Vickers hardness number (VHN) was calculated for each specimen. The current study design was done following Pashley et al. (Pashley et al. 2004), who stated that microhardness was affected by tubular density; as the tubular density increases, the dentin microhardness decreases. Microhardness was evaluated using a Vickers hardness tester. The selection of Vickers microhardness tester rather than the Knoop hardness tester was due to the former's ability of evaluating surface

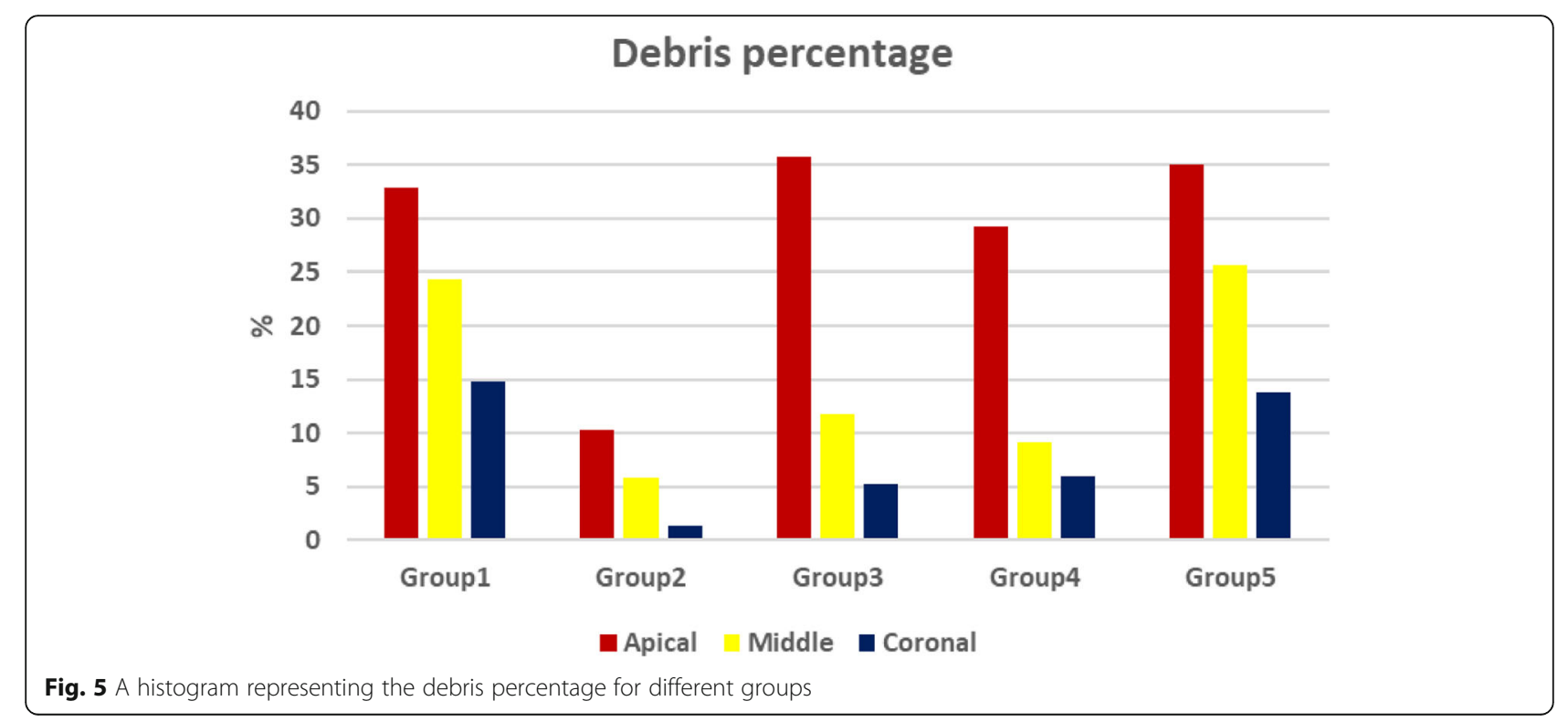




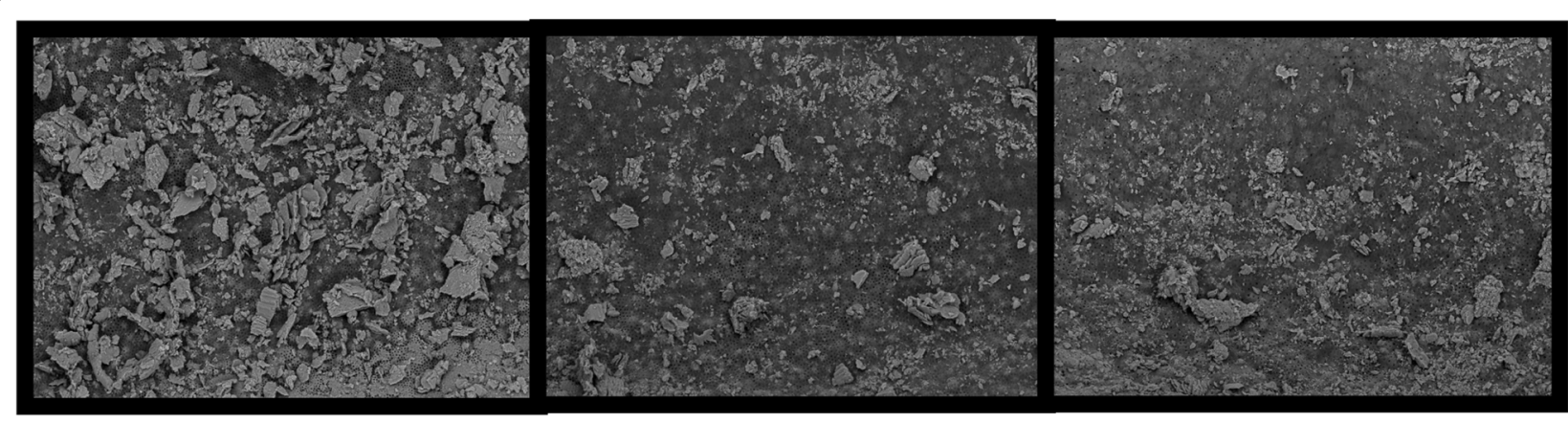

A

B

C

Fig. 6 SEM images of group 1. a Coronal. b Middle. c Apical

changes occurring in deep dental hard tissues. The Knoop hardness tester is limited to superficial dentin at $0.1 \mathrm{~mm}$ rather than deep dentin (Kandil et al. 2014; ALAshou WO. 2011). Although a reduction in microhardness facilitates root canal instrumentation, it may also weaken the root structure leading to fracture of the endodontically treated tooth (Baghdadi and Hassanein 2004; Ossareh and Kishen 2015). The measurement of microhardness indicates indirectly the evidence of mineral loss or gain in dental hard tissues (Panighi and G'Sell 1992; Ten Bosch 1992).

Therefore, this study was aimed to compare the effect of different root canal irrigant solutions on microhardness of the root canal dentin and smear layer removal. Sodium hypochlorite decreased the microhardness in most of the canal thirds; the organic dissolving property of $\mathrm{NaOCl}$ on the collagen component of dentin is an explanation of the cause of microhardness reduction (Cohen et al. 1970). Another possible hypothesis is that when in contact with the dentin, $\mathrm{NaOCl}$ promoted a decrease in the amount of phosphate (Tsuda et al. 1996). The microhardness reduction observed in the present study is in accordance with the results obtained by Oliveira et al. (Oliveira et al. 2007). The concentration and time of action of $\mathrm{NaOCl}$ on dentin interfered with its effect on microhardness (Slutzky-Goldberg et al. 2004), although that effect was not clear in the apical third.

CHX recorded the highest mean hardness values in the apical, middle, and coronal parts. Furthermore, CHX with $M$. oleifera recorded a statistically significant higher mean hardness values than $\mathrm{NaOCl}$ in the apical part. This is found to be in agreement with the finding of Ari et al. (Ari et al. 2004) who concluded that $0.2 \%$ chlorhexidine gluconate seemed to be an appropriate endodontic irrigation solution because of its harmless effect on the microhardness of root canal dentin. Different formulations of $M$. oleifera are considered to increase the dentin microhardness in the three thirds of the canal; this could be attributed to the remineralizing effect of M. oleifera stated by Nagib et al. (Nagib et al. 2016).

The important goal of irrigation is to remove the smear layer and debris (Srirekha et al. 2013).The main two purposes of irrigation are to remove debris (the organic component) and to remove smear layer (mostly

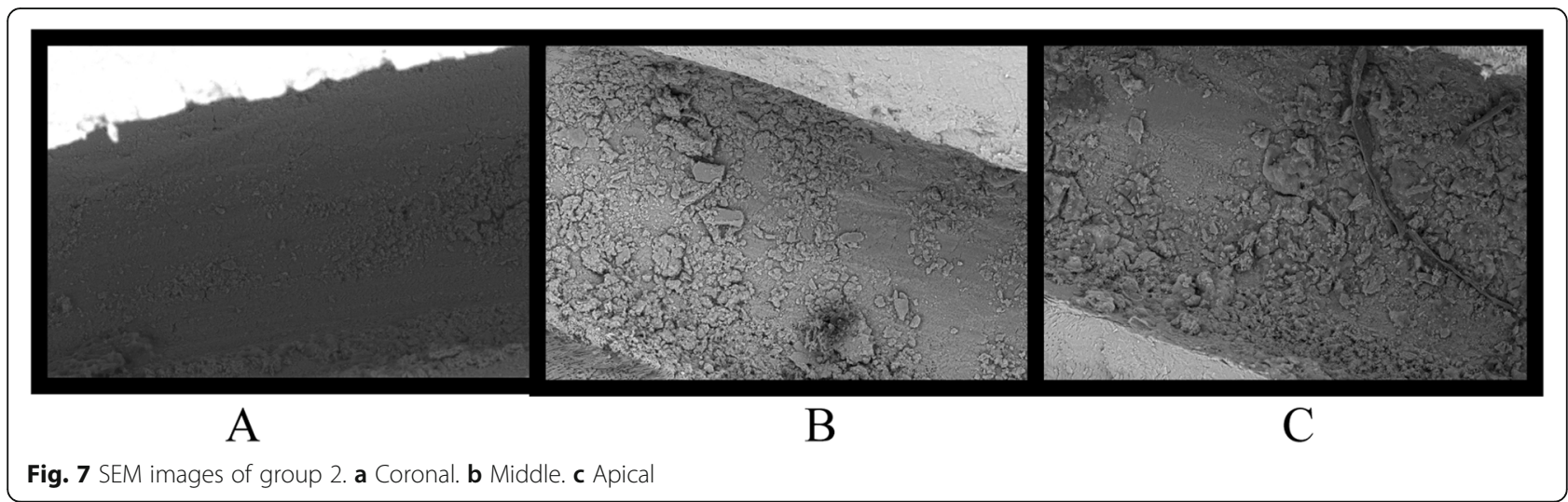




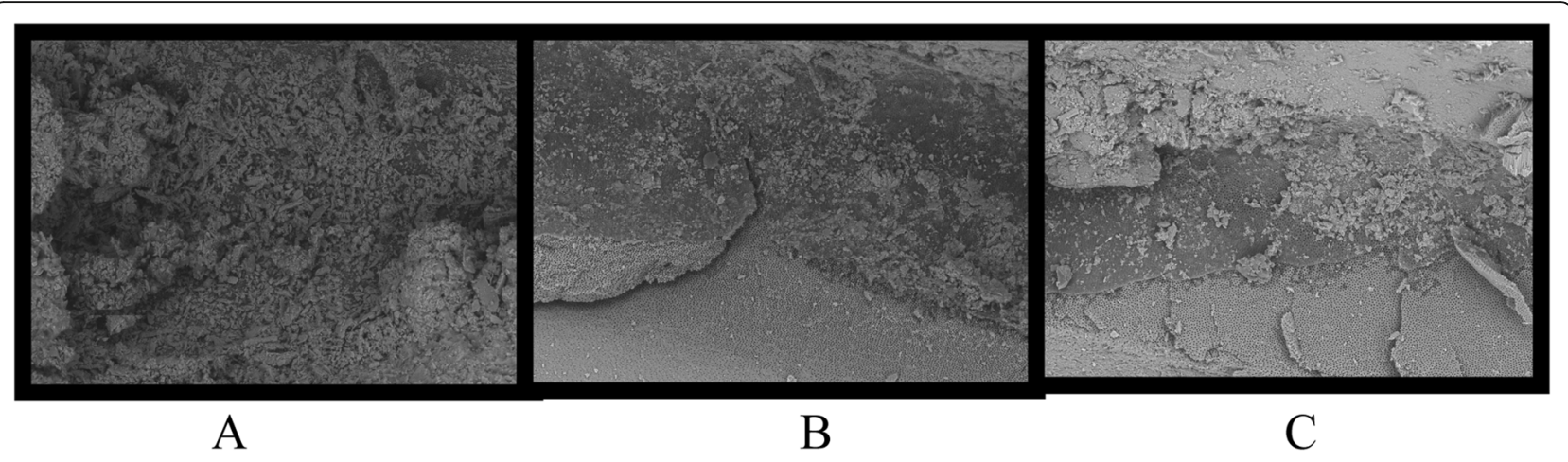

Fig. 8 SEM images of group 3. a Coronal. b Middle. c Apical

the inorganic component) (Sen et al. 1995). An in vitro study conducted by Orstavik and Haapasalo (Orstavik and Haapasalo 1990) showed that the smear layer removal decreased the time needed for dentin disinfection with intracanal medicaments. Other studies have showed that the removal of smear layer led to better adhesion of obturation materials to canal walls (Tidmarsh 1978; White et al. 1984). Scanning electron microscopy has been used to evaluate the ability of the various irrigants to remove the smear layer. SEM allows an examination of the prepared root canal surface morphology (Torabinejad et al. 2003). All irrigants used in this study were able to decrease debris in the coronal third with varying degrees; this is attributed to the increased amount of irrigant reaching the coronal part of the root (Karade et al. 2017). In this study, it was verified that M. oleifera as an irrigant alone or combined with CHX was capable to remove the remaining debris similar to the $\mathrm{NaOCl}$ and $\mathrm{CHX}$. No statistically significant difference was found between the apical, middle, and coronal thirds in these groups. In the middle and apical thirds, the $M$. oleifera irrigant alone showed the lowest debris on the canal wall, and this was also confirmed using the SEM images. This property may be attributed to its high effect as a chelating agent as proven by Zaroul et al. (Zaroual et al. 2014). These results are important for further research on the efficiency of natural herbs used as intracanal irrigant solutions having a similar effect as the routinely used ones.

\section{Conclusions}

- Moringa oleifera increased dentin hardness.

- Moringa oleifera is a promising final irrigant solution alone or combined with chlorhexidine throughout the instrumentation.

\section{Recommendation}

1. With the positive results obtained from this study, further studies should be carried out to investigate the Moringa oleifera antibacterial effect on root canal pathogens.

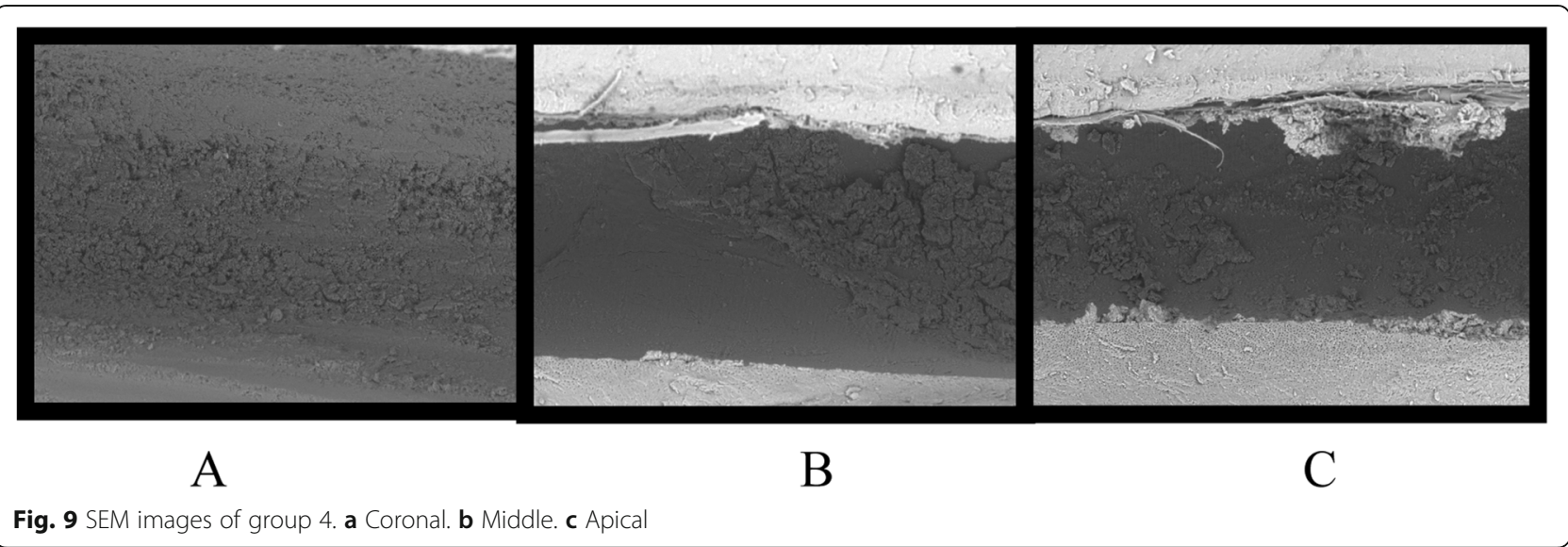




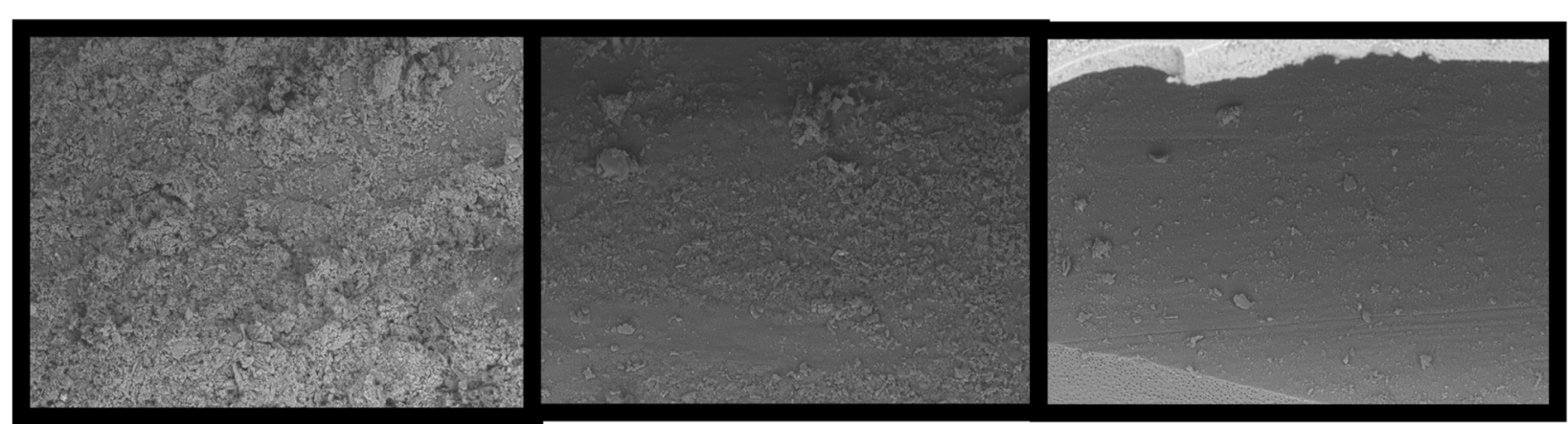

A

B

$\mathrm{C}$

Fig. 10 SEM images of group 5. a Coronal. b Middle. c Apical

2. Further studies should be carried out to investigate the Moringa oleifera ability to be used as a chelating agent compared to EDTA.

\section{Abbreviations}

SEM: Scanning electron microscope; NaOCl: Sodium hypochlorite; M. oleifera: Moringa oleifera; CHX: Chlorhexidine; VHN: Vickers hardness number; EDTA: Ethylenediaminetetraacetic acid

\section{Acknowledgements}

Not applicable in this section.

\section{Authors' contributions}

Dr. Nada Omar and Dr. Yousra Aly performed the biomechanical preparation of the collected specimen using the different types of irrigants. Dr. Maram Khallaf and Dr. Engy Kataia analyzed the data regarding the hardness test, scanning electron microscope, and stereomicroscope. Dr. Yousra Aly and Dr. M. Abdullah Mohamed were major contributors in writing the manuscript. All authors read and approved the final manuscript.

\section{Funding}

National Research Centre project: 11010208

\section{Availability of data and materials}

The authors declare that the data supporting the findings of this study are available within the article.

\section{Ethics approval and consent to participate}

National Research Centre project; Ethics Committee approval number 16/344

\section{Consent for publication}

Not applicable in this section

\section{Competing interests}

The authors declare that they have no competing interests.

Received: 19 February 2020 Accepted: 27 March 2020

Published online: 06 April 2020

\section{References}

Agrawal Vineet S, Rajesh M, Sonali K, Mukesh P (2014) A contemporary overview of endodontic irrigants. A review. Dent App J. 1:105-115

AL-Ashou WO. (2011) The effects of two root canal irrigants and different instruments on dentin microhardness (in vitro study). Al - Rafidain Dent J 1(1):63-70

Anwar F, Latif S, Ashraf M, Gilani AH (2007) Moringa oleifera: a food plant with multiple medicinal uses. Phytother Res 21(1):17-25

Ari H, Erdemir A, Belli S (2004) Evaluation of the effect of endodontic irrigation solution on the microhardness and roughness of root canal dentin. J Endod 30:792-797
Ayhan H, Sultan N, Çirak M, Ruhi MZ, Bodur H (1999) Antimicrobial effects of various endodontic irrigants on selected microorganisms. Int Endod J 32:99102

Baghdadi R, Hassanein I (2004) Effect of different irrigants on same mechanical properties of dentin -an attempt to improve fracture strength and microhardness of endodontically treated teeth. Egyptian Dental J. 50:199208

Cohen S, Stewart GG, Laster LL (1970) The effects of acids, alkalies, and chelating agents on dentine permeability. Oral Surg Oral Med Oral Pathol Oral Radiol Endod 29:631-634 25

Cruz-Filho AM, Sousa-Neto MD, Savioli RN, Silva RG, Vansan LP, Pecora JD (2011) Effect of chelating solutions on the microhardness of root canal Lumen dentin. J Endod 37:358e62

Dubey S (2016) Comparative antimicrobial efficacy of herbal alternatives (Emblica officinalis, Psidium guajava), MTAD, and $2.5 \%$ sodium hypochlorite against Enterococcus faecalis: an in vitro study. Journal of Oral Biology and Craniofacial Research. 6(1):45-48. https://doi.org/10.1016/j.jobcr.2015.12.010

Ferraz CCR, Gomes BPFA, Zaia AA (2001) In vitro assessment of the antimicrobial action and the mechanical ability of the chlorhexidine gel as an endodontic irrigant. J Endod 27:452-455

Ghonmode WN, Balsaraf OD, Tambe VH, Saujanya KP, Patil AK, Kakde DD. Comparison of the antibacterial efficiency of neem leaf extracts, grape seed extracts and $3 \%$ sodium hypochlorite against E. feacalis - an in vitro study. J Int Oral Health. 2013 Dec;5(6):61-66. Epub 2013 Dec 26.

Hasselgren G, Olsson B, Cvek M (1988) Effects of calcium hydroxide and sodium hypochlorite on the dissolution of necrotic porcine muscle tissue. Journal of Endodontics 14:125-127

Jung $L$ (2014) Soluble extract from Moringa oleifera leaves with a new anticancer activity. PLoS One 9(4):e95492

Kandil HE, Labib AH, Alhadainy HA (2014) Effect of different irrigant solutions on microhardness and smear layer removal of root canal dentin. Tan Dent $J$ 11(1):1-11

Karade, Priyatam et al. Efficiency of different endodontic irrigation and activation systems in removal of the smear layer: a scanning electron microscopy study. Iranian Endodontic Journal 12.4 (2017): 414-418. PMC. Web. 31 July 2018.

Kuruvilla JR, Kamath MP (1998) Antimicrobial activity of $2.5 \%$ sodium hypochlorite and $0.2 \%$ chlorhexidine gluconate separately and combined, as irrigants. J Endod 24:472-476

Leonardo MR, Tanomaru Filho M, Silva LAB, Nelson FP, Bonifácio KC, Ito IY (1999) In vivo antimicrobial activity of $2 \%$ chlorhexidine used as a root canal irrigating solution. J Endod 25:167-171

Muhammad OH, Rocca JP, Fornaini C, Medioni E (2015 Dec 30) Evolution of the role of phototherapy during endodontic decontamination. Laser Ther. 24(4): 291-302

Nagib M, Amin L, Khalaf E (2016) Biological effects of topical applications of Moringa oleifera extract versus fluoride on uremic patients extracted teeth. Int J Adv Res 4(9):1513-1520

Oliveira LD, Carvalho CAT, Nunes W, Valera MC, Camargo CHR, Jorge AOC (2007) Effects of chlorhexidine and sodium hypochlorite on the microhardness of root canal dentin. Oral Surg Oral Med Oral Pathol Oral Radiol Endod 104: e125-e128 
Orstavik D, Haapasalo M (1990) Disinfection by endodontic irrigants and dressings of experimentally infected dentinal tubules. Endod Dent Traumatol. 6(4):142-149

Ossareh A, Kishen A. Role of dentin compositional changes and structural loss on fracture predilection in endodontically treated teeth. M.Sc. Thesis. Graduate Department of Dentistry, University of Toronto. 2015; 1-79.

Panighi M, G'Sell CJ (1992) Influence of calcium concentration on the dentin wettability by an adhesive. Biomed Mater Res J. 26:1081-1089

Pashley DH, Tay FR, Yiu C, Mashimoto M (2004) Collagen degradation by host derived enzymes during aging. J Dent Res 83:216e21

Pashley EL, Birdsong NL, Bowman K, Pashley DH (1985) Cytotoxic effects of $\mathrm{NaOCl}$ on vital tissue. J Endod 11:525-528

Sen BH, Wesselink PR, Turkun M (1995) The smear layer: a phenomenon in root canal therapy. Int Endod J. 28:141-148. https://doi.org/10.1111/j.1365-2591. 1995

Siqueira JF Jr, Batista MM, Fraga RC, de Uzeda M (1998) Antibacterial effects of endodontic irrigants on black-pigmented gram-negative anaerobes and facultative bacteria. J Endod 24:414-416

Slutzky-Goldberg I, Maree M, Liberman R, Heling I (2004) Effect of sodium hypochlorite on dentin microhardness. J Endod 30:880-882

Srirekha A, Rashmi K, Hegde J, Lekha S, Rupali K, Reshmi G (2013) An in vitro evaluation of passive ultrasonic agitation of different irrigants on smear layer removal after post space preparation: a scanning electron microscopic study. $J$ Indian Prosthodont Soc. 13(3):240-246

Ten Bosch JJ (1992) Demineralization and remineralization evaluation techniques. Dent Res J. 71:924-928

Tidmarsh BG (1978) Acid-cleansed and resin-sealed root canals. J Endod. 4(4): $117-121$

Torabinejad M, Khademi AA, Babagoli J, Cho Y, Johnson WB, Bozhilov K (2003) A new solution for the removal of the smear layer. J Endod 29:170e5

Tsuda H, Ruben J, Arends J (1996) Raman spectra of human dentin mineral. Eur J Oral Sci 104:123-131 26

White RR, Goldman M, Lin PS (1984) The influence of the smeared layer upon dentinal tubule penetration by plastic filling materials. J Endod. 10(12):558562

Zaroual A, El Qouatli S, Bellochou A, Najih R, Chtaini A (2014) Electrochemical study of the capacity of Moringa oleifera to chelate heavy metals. Pharm Anal Acta 5:310. https://doi.org/10.4172/2153-2435.1000310

Zehnder M (2006) Root canal irrigants. J Endod 32:389-398

Zehnder M, Kosicki D, Luder H et al (2002) Tissue-dissolving capacity and antibacterial effect of buffered and unbuffered hypochlorite solutions. Oral Surg Oral Med Oral Pathol Oral Radiol Endod 94:756-762

Zhu WC, Gyamfi J, Niu LN et al (2013) Anatomy of sodium hypochlorite accidents involving facial ecchymosis—a review. J Dent 41:935-948

\section{Publisher's Note}

Springer Nature remains neutral with regard to jurisdictional claims in published maps and institutional affiliations.

\section{Submit your manuscript to a SpringerOpen ${ }^{\circ}$ journal and benefit from:}

- Convenient online submission

- Rigorous peer review

- Open access: articles freely available online

- High visibility within the field

- Retaining the copyright to your article

Submit your next manuscript at $\boldsymbol{\nabla}$ springeropen.com 